\title{
Serum TNF- $\alpha$ in psoriasis after treatment with propylthiouracil, an antithyroid thioureylene
}

\author{
Alan N Elias*1, Vanda S Nanda² and Raj Pandian ${ }^{3}$
}

\begin{abstract}
Address: ${ }^{1}$ Department of Medicine, Division of Endocrinology and Metabolism, University of California, Irvine Medical Center, 101 The City Drive, Orange, California 92868, USA, ${ }^{2}$ Department of Dermatology, University of California, Irvine Medical Center, 101 The City Drive, Orange, California 92868, USA and ${ }^{3}$ Quest Diagnostics, 33608 Ortega Highway, San Juan Capistrano, California 92690, USA

Email: Alan N Elias* - anelias@uci.edu; Vanda S Nanda - vsnanda@uci.edu; Raj Pandian - raj.m.pandian@questdiagnostics.com

* Corresponding author
\end{abstract}

Published: 30 April 2004

BMC Dermatology 2004, 4:4
Received: II January 2004

Accepted: 30 April 2004

This article is available from: http://www.biomedcentral.com/147I-5945/4/4

(C) 2004 Elias et al; licensee BioMed Central Ltd. This is an Open Access article: verbatim copying and redistribution of this article are permitted in all media for any purpose, provided this notice is preserved along with the article's original URL.

\begin{abstract}
Background: Tumor necrosis factor- $\alpha$ (TNF- $\alpha)$ and its receptors play important roles in the development and persistence of psoriatic plaques. The antithyroid thioureylenes, propylthiouracil and methimazole, are effective in the treatment of patients with psoriasis with a significant number of patients showing clearing or near clearing of their lesions after a several weeks of treatment.

Methods: The present study examined the effect of treatment with propylthiouracil, given in a dose of $100 \mathrm{mg}$ every 8 hours for 3 months, on the serum levels of TNF- $\alpha$ in 9 patients with plaque psoriasis.

Results: Propylthiouracil therapy did not result in a significant decline in serum TNF- $\alpha$ concentrations.

Conclusions: The findings suggest that the therapeutic effect of propylthiouracil in psoriasis appears not to be related to any change in the concentration of TNF- $\alpha$ but occurs via an antiproliferative mechanism as we have previously speculated.
\end{abstract}

\section{Background}

Psoriasis is a common skin disorder that affects approximately 2.8 percent of the population and is associated with morbidity that is comparable that seen with life threatening disease $[1,2]$. There is a clearly established genetic predisposition to the disease $[3,4]$ that is often triggered by the processing of bacterial, viral or chemical antigens by skin antigen presenting cells (APC) or Langerhans cells [5-9]. The disease is presently believed to be a T cell disorder that leads to keratinocyte proliferation $[6,10,11]$. Plaque formation in the disease reflects both the effects of accelerated proliferation as well as reduced apoptosis in proliferated keratinocytes $[12,13]$. The events responsible for keratinocyte proliferation have been extensively reviewed [12]. An important cytokine that is associated with keratinocyte proliferation in psoriasis is TNF- $\alpha$.. TNF- $\alpha$ concentrations are higher in psoriatic lesions than in unaffected skin of psoriatic patients and tend to decline with clearing of the lesions after effective therapy [14-16]. This cytokine is produced by keratinocytes and leads to an increased expression of cellular adhesion molecules that promote, propagate, and amplify the immune signals that are responsible for maintaining the events that lead to psoriasis. Recently introduced therapeutic approaches in the management of psoriasis depend on blocking TNF- $\alpha$ binding to its receptor by using TNF- $\alpha$ hybrid antibodies. Patients treated with such agents very often show marked improvement in their disease with 
major clearing in several instances [17-19]. Present day therapy of the disease is not particularly satisfactory and the many therapies currently in use are associated with significant cumulative toxicity [17]. The antithyroid thioureylenes have been used in the treatment of patients with hyperthyroidism, particularly Graves' disease, and have well-defined and very limited toxicity. They have been used for management of patients with Graves' hyperthyroidism for many years without any significant problems. We and others have described the effectiveness of these agents in the treatment of patients with plaque psoriasis [20-24]. The mechanism of action of these drugs in psoriasis is unknown but some evidence points to their ability to act as anti-proliferative agents. The drugs reduce expression of proliferative cell nuclear antigen (PCNA) a marker of cellular proliferation [25]. Since plaque formation is psoriasis is dependent on enhanced proliferation of keratinocytes particularly in the basal layers of the epidermis any agent that could reduce this critical event in the pathogenesis of psoriasis would lead to clinical improvement. The present study was performed to examine the effect of treatment with propylthiouracil on circulating TNF- $\alpha$ in patients with stable plaque psoriasis.

\section{Methods \\ Patients}

Nine patients ( 6 male, 3 female) enrolled in the study. The patients ranged in age from 21 to 65 years (mean \pm $\mathrm{SD}, 44 \pm 16 \mathrm{yrs}$ ). None of the patients received phototherapy or systemic treatment for six weeks and none used topical therapy other than emollients for six weeks prior to entry into the study. Patients with allergies to sulfa medication, pregnant patients, and patients with a known diagnosis of thyroid dysfunction were excluded from participating in the study. All patients signed an informed consent document approved by the Institutional Review Board of the University of California, Irvine. The enrolled volunteers had a complete blood count (CBC) and measurement of thyroid stimulating hormone (TSH) before starting treatment with propylthiouracil (PTU). CBC and TSH measurements were obtained again at 2 weeks and later at 4,8 and 12 weeks. In addition, blood was removed for measurement of TNF- $\alpha$ prior to PTU treatment and again at 2, and 12 weeks later. The blood for TNF- $\alpha$ measurements was collected in tubes containing peptide inhibitors, and the serum removed and stored at $-70^{\circ} \mathrm{C}$ until assayed. Patients were instructed to take $100 \mathrm{mg}$ PTU every 8 hours for twelve weeks.

\section{Clinical assessment}

Clinical evaluation was performed by a single dermatologist (VSN). Evaluation was performed before enrollment, and again at 4, 8 and 12 weeks after PTU therapy. Assessment was made using the PASI scoring system.

\section{Measurement of TNF- $\alpha$}

TNF- $\alpha$ levels in serum were measured using a highly sensitive commercially available assay from R\&D Systems (Minneapolis, MN). The assay is a sandwich enzyme immunoassay (ELISA) with an analytical sensitivity of < $0.2 \mathrm{pg} / \mathrm{ml}$. Intra- and interassay variations are less than 11.3 and $14.7 \%$ respectively. The reference range for normal volunteers is between 1.2 and $15.3 \mathrm{pg} / \mathrm{ml}$.

\section{Statistical analysis}

Statistical analysis was performed using Student's $t$ test for paired and grouped data. P of $<0.05$ was considered significant.

\section{Results \\ Clinical scores}

All patients showed clinical improvement with PASI scores declining from $20.1 \pm 6.6$ to $15.8 \pm 4.9$ at 4 weeks $(\mathrm{P}<0.02), 11.0 \pm 4.8$ at 8 weeks $(\mathrm{p}<0.0001)$ and $6.7 \pm$ 4.3 after 12 weeks $(\mathrm{p}<0.0001)$ of PTU therapy.

\section{Serum TNF- $\alpha$ concentrations}

Serum TNF- $\alpha$ concentrations were $5.1 \pm 2.3 \mathrm{pg} / \mathrm{ml}$ before treatment and did not show significant decline at 2 weeks $(5.1 \pm 2.16 \mathrm{pg} / \mathrm{ml})$ and 12 weeks $(4.96 \pm 2.8 \mathrm{pg} / \mathrm{ml})$ of treatment.

\section{Side effects}

None of the patients experienced any side effects from PTU treatment. As previously described, white blood count remained within the normal range during the entire study, the serum TSH concentration did not rise above the upper normal range, and neither did any patient develop signs or symptoms of hypothyroidism.

\section{Discussion}

Activated Th1 cells which produce TNF- $\alpha$ and interferon$\gamma($ IFN- $\gamma$ ) are important in the pathogenesis of psoriasis $[12,26]$. These cytokines promote expression of adhesion molecules such as intercellular adhesion molecule 1 (ICAM-1), and vascular cell adhesion molecule (VCAM) on keratinocytes and vascular endothelial cells thereby facilitating migration of additional pro-inflammatory cells to the area of the psoriatic plaque resulting in the cytokine cascade that ultimately results in enhanced keratinocyte proliferation and formation of the lesions characteristic of the disease [27] Keratinocytes that have undergone proliferation, as well as dendritic cells and skin macrophages, produce TNF- $\alpha$ that leads to an amplification of the Th1 role in formation of the psoriatic plaque. In recent months there have been several studies that have exploited the use of designer antibodies directed against the binding of TNF- $\alpha$ to its receptor (etanercept) [19] or that prevent the association of leucocyte-function associated antigen (LFA) and ICAM-1 (efalizumab) [28]. There 
is significant clinical improvement in patients treated with these agents. There is, however, loss of clinical benefit after the drugs are stopped and a small proportion of patients develop antibodies to the agents which is likely to limit there efficacy with repeated use. The antithyroid thioureylenes, in contrast, are easily administered oral medications that cost a mere fraction of the amount necessary to treat a patient with psoriasis with a designer antibody. The mechanism of action of antithyroid thioureylenes in psoriasis is unclear. Based on our previous observations, the drugs do not appear to produce any change in circulating IL-2 receptor or ICAM-1 [29], and lack effects on pro-inflammatory cytokines such as IL-12 or anti-inflammatory cytokines such as IL-10 [30]. The drugs do, however, produce a significant decline in markers of cellular proliferation, particularly in proliferative nuclear cell antigen (PCNA) expression [25] suggesting that the principal therapeutic benefit of these drugs in psoriasis may be exerted via their anti-proliferative effect.

\section{Conclusions}

The lack of any effect on circulating TNF- $\alpha$ in this study argues against any effect of propylthiouracil on keratinocyte production of TNF- $\alpha$. Since PTU and other antithyroid thioureylenes cause a decrease in keratinocyte proliferation one would expect a fall in TNF- $\alpha$ concentration after use of these agents in patients showing significant clinical improvement. The fact that this did not occur requires further investigation.

\section{Competing interests \\ None declared.}

\section{Authors' contributions}

ANE was involved in the developing the hypothesis for the study design and writing the manuscript; VSN recruited the patients for the study and performed the necessary clinical assessments; RP assisted with the assay of TNF- $\alpha$.

\section{References}

I. Linden KG, Weinstein GD: Psoriasis: current perspectives with an emphasis on treatment. Am J Med 1999, I07:595-605.

2. Greaves MW, Weinstein GD: Treatment of psoriasis. N Engl J Med 1995, 332:581-588.

3. Krueger GG, Duvic M: Epidemiology of psoriasis: clinical issues. J Invest Dermatol 1994, I02: |4S- I8S.

4. Bowcock AM, Barker JN: Genetics of psoriasis: the potential impact on new therapies. I Am Acad Dermatol 2003, 49:S5I-56.

5. Barker JN: The pathophysiology of psoriasis. Lancet I99I, 338:227-230.

6. Nickoloff BJ, Schroder JM, von den Driesch P, Raychaudhuri SP, Farber EM, Boehncke WH, Morhenn VB, Rosenberg EW, Schon MP, Holick MF: Is psoriasis a T-cell disease? Exp Dermatol 2000, 9:359-375

7. Nickoloff BJ, Wrone-Smith T: Superantigens, autoantigens, and pathogenic $\mathbf{T}$ cells in psoriasis. J Invest Dermatol I998, I I 0:459-460.

8. England RJ, Strachan DR, Knight LC: Streptococcal tonsillitis and its association with psoriasis: a review. Clin Otolaryngol 1997, 22:532-535.
9. Skov L, Baadsgaard O: Bacterial superantigens and inflammatory skin diseases. Clin Exp Dermatol 2000, 25:57-6I.

10. Nickoloff $B$ J: Creation of psoriatic plaques: the ultimate tumor suppressor pathway. A new model for an ancient T-cellmediated skin disease. Viewpoint. J Cutan Pathol 200I, 28:57-64.

II. Nickoloff BJ: The immunologic and genetic basis of psoriasis. Arch Dermatol 1999, I35: I 104-III0.

12. Asadullah K, Docke WD, Volk HD, Sterry W: The pathophysiological role of cytokines in psoriasis. Drugs Today (Barc) 1999, 35:913-924.

13. Wrone-Smith T, Mitra RS, Thompson CB, Jasty R, Castle VP, Nickoloff $B J$ : Keratinocytes derived from psoriatic plaques are resistant to apoptosis compared with normal skin. Am J Pathol 1997, 15 I:1321-1329.

14. Mussi A, Bonifati C, Carducci M, D'Agosto G, Pimpinelli F, D'Urso D, D'Auria L, Fazio M, Ameglio F: Serum TNF-alpha levels correlate with disease severity and are reduced by effective therapy in plaque-type psoriasis. J Biol Regul Homeost Agents 1997, II:II5-II8.

15. Bonifati C, Carducci M, Cordiali Fei P, Trento E, Sacerdoti G, Fazio $\mathrm{M}$, Ameglio F: Correlated increases of tumour necrosis factoralpha, interleukin-6 and granulocyte monocyte-colony stimulating factor levels in suction blister fluids and sera of psoriatic patients - relationships with disease severity. Clin Exp Dermatol 1994, 19:383-387.

16. Ettehadi P, Greaves MW, Wallach D, Aderka D, Camp RD: Elevated tumour necrosis factor-alpha (TNF-alpha) biological activity in psoriatic skin lesions. Clin Exp Immunol 1994, 96: I46-I5I.

17. Gottlieb AB, Chaudhari U, Mulcahy LD, Li S, Dooley LT, Baker DG: Infliximab monotherapy provides rapid and sustained benefit for plaque-type psoriasis. J Am Acad Dermatol 2003, 48:829-835.

18. Chaudhari UP, Romano P, Mulcahy LD, Dooley LT, Baker DG, Gottlieb $A B$ : Efficacy and safety of infliximab monotherapy for plaque-type psoriasis: a randomised trial. Lancet 200I, 357:1842-1847.

19. Leonardi CL, Powers JL, Matheson RT, Goffe BS, Zitnik R, Wang A, Gottlieb AB: Etanercept as monotherapy in patients with psoriasis. N Engl J Med 2003, 349:2014-2022.

20. Elias AN, Barr RJ: Low-dose oral propylthiouracil in the treatment of plaque psoriasis. Int J Dermatol 1995, 34:5 19-520.

21. Elias AN, Goodman MM, Liem WH, Barr RJ: Propylthiouracil in psoriasis: results of an open trial. J Am Acad Dermatol 1993, 29:78-8I.

22. Elias AN, Goodman MM, Rohan MK, Alpern K, Barr RJ: Methimazole (2-mercapto I-methyl imidazole) in psoriasis - results of an open trial. Dermatology 1993, 187:26-29.

23. Kose K, Utas S, Yazici C, Akdas A, Kelestimur F: Effect of propylthiouracil on adenosine deaminase activity and thyroid function in patients with psoriasis. $\mathrm{Br} J$ Dermatol 200I, 144: || $|2|-|| 26$.

24. Utas S, Kose K, Yazici C, Akdas A, Kelestimur F: Antioxidant potential of propylthiouracil in patients with psoriasis. Clin Biochem 2002, 35:24I-246.

25. Elias AN, Barr RJ, Rohan MK, Dangaran K: Effect of orally administered antithyroid thioureylenes on PCNA and P53 expression in psoriatic lesions. Int J Dermatol 1995, 34:280-283.

26. Baadsgaard O, Fisher G, Voorhees JJ, Cooper KD: The role of the immune system in the pathogenesis of psoriasis. J Invest Dermatol 1990, 95:32S-34S.

27. Uyemura K, Yamamura M, Fivenson DF, Modlin RL, Nickoloff B]: The cytokine network in lesional and lesion-free psoriatic skin is characterized by a T-helper type I cell-mediated response. J Invest Dermatol 1993, 101:701-705.

28. Gordon KB, Papp KA, Hamilton TK, Walicke PA, Dummer W, Li N, Bresnahan BW, Menter A: Efalizumab for patients with moderate to severe plaque psoriasis: a randomized controlled trial. JAMA 2003, 290:3073-3080.

29. Elias AN, Goodman MM, Rohan MK: Serum ICAM-I concentrations in patients with psoriasis treated with antithyroid thioureylenes. Clin Exp Dermatol 1993, 18:526-529.

30. Elias AN, Nanda VS, Barr RJ: Effect of PTU on IL- 12 and IL- 10 in psoriasis. J Drugs Dermatol 2003, 2:645-648. 


\section{Pre-publication history}

The pre-publication history for this paper can be accessed here:

http://www.biomedcentral.com/1471-5945/4/4/prepub

Publish with Bio Med Central and every scientist can read your work free of charge

"BioMed Central will be the most significant development for disseminating the results of biomedical research in our lifetime. " Sir Paul Nurse, Cancer Research UK

Your research papers will be:

- available free of charge to the entire biomedical community

- peer reviewed and published immediately upon acceptance

- cited in PubMed and archived on PubMed Central

- yours - you keep the copyright 